\title{
A Study on the Altruism Levels of Physical Education Teachers in Kütahya
}

\author{
Recep Baybars Eynur \\ Faculty of Sports Sciences \\ Dumlupınar University, Kütahya, Turkey \\ Tel: 90-532-591-3977Ｅ-mail: baybars.eynur@dpu.edu.tr \\ Oğuz Akalan \\ Faculty of Sports Sciences \\ Dumlupınar University, Kütahya, Turkey \\ Tel: 90-539-254-2525_E-mail: oguzakalan4343@gmail.com \\ Yunus Şahinler (Corresponding author) \\ Faculty of Sports Sciences \\ Dumlupınar University, Kütahya, Turkey \\ Tel: 90-535-832-3873 E-mail: yunusahinler@gmail.com
}

Received: September 13, $2020 \quad$ Accepted: October 21, 2020

Published: November 2, 2020

doi:10.5296/jei.v6i2.17741 URL: https://doi.org/10.5296/jei.v6i2.17741

\begin{abstract}
The aim of this study is to examine the altruism levels of the physical education teachers working in Kütahya. 105 physical education teachers, 53.3\% female and 46.7\% male, participated in the research. The altruism scale created by Ersan and Çabuker was used in the study. T-test and ANOVA were used for independent samples in the research statistics, and Bonferroni and Tamhane were used for the difference of subgroups $(\mathrm{a}=0.05)$. In the normality tests conducted according to the variables, Mann Whitney U and Kruskal Wallis $\mathrm{H}$ Tests were used for dependent variable results that did not show normal distribution $(\mathrm{a}=$ 0.05). According to the research results, it was found that there was a significant difference in
\end{abstract}


the selfishness sub-dimension of female physical education teachers compared to male physical education teachers $(\mathrm{p}<0.05)$. According to the results of the research, it was determined that there was a significant difference between the groups in all total scores according to the residence place of physical education teachers $(p<0.05)$. In the subgroup analysis, a significant difference was found between the self-sacrifice, selfishness and altruism scores of physical education teachers residing in the town and metropolitan area $(\mathrm{p}<$ 0.05). According to the variable of the alma mater, a significant difference was found between the graduates of college and the graduates of the Institute in favour of the graduates of the selfishness sub-dimension $(\mathrm{p}<0.05)$. This revealed that college graduates displayed less selfish behaviour than the graduates of the Institute.

Keywords: Physical education, Alturism, Teacher, Secondary education, Primary education, High school

\section{Introduction}

As the basic product of educational activities, it is easily understandable that even the simplest form of life will reach the desired point by putting great effort on human. The fact that the results to be obtained in the length and continuation of the training processes can be evaluated at the end of this long period of time also put the studies into difficult processes. From this point of view, everyone is aware that altruism is as important as formation knowledge, field knowledge and general culture knowledge in the professional duties of teachers whose job is to train people but the altruism feature, which is not defined or tried to be given in implicit programs, can be seen among the indispensable criteria of the teaching profession.

Various definitions have been made for the concept of altruism in the current situation. In this study, it is thought that enough information was given about the concept of altruism under the altruism subtitle. However, there are definitions obtained from basic sources related to the concept of altruism as the subject of the problem.

With this study, it is aimed to gain information about the extent of physical education teachers within the field, and to what extent the process should be examined within the scope of the concept of altruism regarding physical education teaching.

By definition, altruism is defined as beneficial behaviour, which is done voluntarily and without waiting for reward for an individual in a need help (Bakirciolu, 2016).

Helping another person in a difficult period is one of the most satisfying jobs. At the same time, facts such as social interest, altruism and helpfulness are considered as one of the most basic signs of mental health (Tekinalp \& Içı, 2013).

It is also stated in the studies that an activity such as organ donation may seem crazy for many people, but basically the feeling of altruism should be emphasized as the primary source of motivation (Down, 2011; Healy, 2006; Seglow, 2004). A similar situation can be said for people who help the people with AIDS in Africa (Swidler \& Watkins, 2017). Also, creating various funds for this and similar benefits has been reported (Smith, 2014). It should 
not be forgotten that motivation is stated as the main factor in the formation of altruism (Scott $\&$ Seglow, 2007). It is seen that the existence of financial and ethical values among these motivational factors is also discussed (Monroe, 1996). The existence of such a lofty value has also been identified in all religions (Oord, 2008). It is stated that altruism as an element been found in love, religion and science. In another study, altruism was defined as an "Athenian Behaviour" (Christ, 2012).

In terms of definition, it is easily predicted that the concept of altruism has an important place especially in the teaching profession. In this context, the subject altruism was systematically evaluated for not only Kütahya but also all researchers all over Turkey.

\subsection{Altruism}

Schools play an important role in conveying values to students. At this point, although there is no consensus on what values will be taught to students, the values expected to be taught and to be transformed into behaviour in a democratic school culture can be listed as tolerance, fairness, equality, peace, diligence, love, respect for differences, integrity, honesty, benevolence, patriotism, independence, freedom, pluralism, altruism (feeling responsible for others), sensitivity, solidarity, compassion, responsibility, success and happiness (Acun, 2018). It is seen that motivation of teachers in this regard is very important for behaviour to occur (Scott \& Seglow, 2007). Kant argues that we are in charge of to be altruistic by asking us to imagine a specific situation of someone with great prosperity and success (Scott \& Seglow, 2007). It is stated in Kant studies that it is not possible for man to live in isolation from other people and that the basis of this union should be formed with altruism. Otherwise, it was stated that it is not possible for a person to achieve his own goals and to meet their needs with on his own (Scott \& Seglow, 2007).

Social psychologists, like other social scientists and social philosophers, have been interested in what has long been called the "altruism paradox". The paradox of altruism sometimes stems from individuals taking selfless actions that benefit others. This contradicts the assumption that individuals in most motivational theories only act beneficially for themselves. There are two basic ways to solve the altruism paradox. One way is to try to identify the underlying personal benefits, perhaps to motivate apparently altruistic prosocial behaviour. The second way is to claim that individuals engage in behaviour that benefits others, regardless of any benefit to them. Theories and research on prosocial behaviour make use of either way to solve the altruism paradox (Fultz \& Schafer, 2019).

It seems that there are a number of approaches to the full understanding of the concept. Among these, simulation focused studies draw attention. It is seen that studies related to altruism are evaluated in terms of both biology and social sciences. In the social sciences dimension, with the collaboration between animals, these studies have made researches in different areas of altruism, as well as being selfish as much as they do not want for success, although they receive various kinds of education about moral values. The screams of a seal as an alarm to notify other seals seeing a shark or the scream of the herd that sees a predator like a hawk is seen as an example of an altruism in animals (Arnold, 2008; Grant, 2001). According to the data obtained, it is stated that altruism is a socio-biological based feeling 
(Grant, 2001; Salter, 2004).

In another study, they argued that the concept of altruism passed from animals to humans with the concept of blood brotherhood and so it was made sense by some societies. They subsequently claimed that altruism was a movement with a goodness in its centre and that its centre was the heart. In line with the studies carried out, they suggested that questions based on political, political, philosophical or even religion should be scientifically defined (Dugatkin, 2011).

In another study, it is stated that altruism is in the form of benevolent behaviour, empathy and prosocial behaviour and it is a value that should be in individuals (Post, 2003). It is seen that individuals expect this kind of behaviour from their parents as an altruist behaviour that increases the interaction between generations, as well as cultural issues, which they expect from their families and that it is their parents' duty to provide free money to them (Kotlikoff, 2000; Stark, 1995). In this respect, the individual sees the source of the altruist behaviour first as a family and then adopts his teacher as the first place he expects in line with his expectations and development for different purposes.

When the concept is analysed, it is seen that schools, which are the primary element of raising individuals, are

an important institution to make the society defined as "Nation" within the scope of values education.

In this context, it is anticipated that teachers should make an intensive effort to raise awareness. Because, it is stated that the response of the difficult processes experienced in the raising process will only emerge as a result of altruist behaviours (Couture, 1998). In addition, Considering that sufficient workforce is considered as the locomotive of the economy, it is emphasized that providing individuals with the right to a job and providing them with the awareness that the discipline is right by people instead of strict rules and boring life is a very important and necessary situation in the development of the nation and the state (Koppel, 2013).

\section{Method}

The research is a study in the survey model. Survey models are research approaches aiming to describe a situation that exists in the past or an existing situation as it exists. The event, individual or object that is the subject of the research is tried to be defined in its own conditions and as it is. No effort is made to change or influence them in any way. There is something to be known and it is there. The important thing is to be able to "observe" and describe it appropriately (Karasar, 2005).

\subsection{Study Group}

105 physical education teachers working in public schools in Kütahya participated in the study. Kütahya has 110 physical education. The distribution of physical education teachers in the study group according to their gender is given in the table below. 
Table 1. Distribution of physical education teachers participating in the research by gender

\begin{tabular}{|c|c|c|c|c|c|}
\hline \multicolumn{3}{|c|}{ Frequency } & \multirow{2}{*}{$\begin{array}{l}\text { \% } \\
53.3\end{array}$} & \multirow{2}{*}{$\begin{array}{l}\text { Valid \% } \\
53.3\end{array}$} & \multirow{2}{*}{$\begin{array}{l}\text { Cumulative \% } \\
53.3 \\
\end{array}$} \\
\hline$\stackrel{0}{0}$ & Female & 56 & & & \\
\hline$\cdot \frac{\vec{\pi}}{\tilde{E}}$ & Male & 49 & 46.7 & 46.7 & 100.0 \\
\hline & Total & 105 & 100.0 & 100.0 & \\
\hline
\end{tabular}

It was determined that $53.3 \%(\mathrm{~N}=56)$ of physical education teachers participating in the study were female and $46.7 \%(\mathrm{~N}=49)$ were male.

In the research, the altruism scale developed by Ersanlı and Çabuker (2015) was used to determine the altruism levels of physical education teachers. This scale consists of 20 questions. It is a 5-point Likert type scale. The scale is divided into "least" and "most frequent" grades. The total variance explained by the scale is $42.967 \%$. The lowest score that can be obtained from Altruism Scale is -10 and the highest score is 70 (Ersanlı \& Çabuker, 2015). In the study, scale total internal consistency coefficient was found as $(A=0.76)$. The scale is a scale consisting of two sub-dimensions as self-sacrifice and selfishness, and in obtaining the total score of the scale, it is obtained by subtracting the self-worth sub-dimension total score from the total dedication score.

In addition, many different studies provide information about the use of the scale (Dali \& Özkara, 2017; Gülsoy \& Topal, 2018; Gürsoy, Köksal, \& Yapar, 2018; Öztürk \& Ersanli, 2018; Yeşilkaya \& Yı1dız, 2018).

\subsection{Data Evaluation and Statistical Processes}

Within the scope of the research, the data obtained from the measurements were tried to be evaluated by using the SPSS 25 program. While in the normality tests conducted according to the independent variables of the teachers in the research group, independent sample t-test and one-way ANOVA Tests, which are parametric tests, were used for the groups that fit the normal distribution, in the normality test conducted according to independent variables, the Mann Whitney $U$ test or Kruskall Wallis $H$ Test was used for the data not fitting normal distribution. In the research, the level of significance was accepted as $(A=0.05)$.

\section{Results}

The findings obtained from the study were analysed in accordance with the scale used in the research in accordance with the independent variables and sub-dimensions and the total score of the scale were compared with the independent variables sub-titles.

\subsection{Examining Altruism Levels of Physical Education Teachers According to Gender Variable}

The comparisons of the self-sacrifice, selfishness and scale total scores of the physical education teachers participating in the research are given in the table below. 
Table 2. Self-sacrifice, selfishness and scale total score T-test results according to the gender variable of physical education teachers participating in the research

\begin{tabular}{|c|c|c|c|c|c|c|}
\hline & Gender & $\mathbf{N}$ & $\overline{\mathbf{X}}$ & Ss & $t$ & $\mathbf{P}$ \\
\hline \multirow{2}{*}{ Self-Sacrifice } & Female & 56 & 63.0714 & 7.19560 & \multirow{2}{*}{1.036} & \multirow{2}{*}{.303} \\
\hline & Male & 49 & 61.5918 & 7.41597 & & \\
\hline \multirow{2}{*}{ Selfishness } & Female & 56 & 8.5714 & 4.41838 & \multirow{2}{*}{-2.183} & \multirow{2}{*}{0.032} \\
\hline & Male & 49 & 10.6327 & 5.15871 & & \\
\hline \multirow{2}{*}{ Altruism } & Female & 56 & 54.5000 & 9.97998 & \multirow{2}{*}{1.806} & \multirow{2}{*}{0.07} \\
\hline & Male & 49 & 50.9592 & 10.07670 & & \\
\hline
\end{tabular}

When Table 2 is examined, while there is no significant difference between the gender sub-dimensions and altruism total scores of the physical education teachers participating in the study $\left(\mathrm{t}_{.05}=1.036 ; \mathrm{p}>0.05 ; \mathrm{t}_{.05}=1.806 ; \mathrm{p}>0.05\right)$, a significant difference $\left(\mathrm{t}_{.05}=-2.183\right.$; $\mathrm{p}<0.05$ )was observed in favour of male physical education teachers.

$(\mathrm{N}=49 ; \overline{\mathrm{X}}=10.6327 \pm 5.15871$ ) in the sub-dimension of selfishness (in fact, because selfishness is an undesired behaviour), when compared to the female physical education teachers $(\mathrm{N}=56 ; \overline{\mathrm{X}}=8.5714 \pm 4.41838)$.

3.2 Examination of Altruism Levels of Physical Education Teachers According to the Place of Residence

Below, the levels of altruism of the physical education teachers participating in the study are examined according to their place of residence.

Table 3. Self-sacrifice sub-dimension one-way ANOVA Test results of physical education teachers participating in the study according to the place of residence

\begin{tabular}{|l|l|l|l|l|l|l|l|}
\hline & & $\mathbf{N}$ & $\overline{\mathbf{X}}$ & $\mathbf{S s}$ & $\boldsymbol{F}$ & $\mathbf{p}$ & Sub-Group \\
\hline \multirow{5}{*}{ Self-Sacrifice } & Town & 51 & 64.6667 & 7.40990 & 5.838 & .004 & Town>Metropolitan \\
\cline { 2 - 8 } & Province & 34 & 60.9706 & 6.35555 & & & \\
\cline { 2 - 9 } & Metropolitan & 20 & 58.9500 & 6.87080 & & & \\
\cline { 2 - 8 } & Total & 105 & 62.3810 & 7.30171 & & & \\
\hline
\end{tabular}

As a result of the comparisons made according to the place of residence, a significant difference was found between the self-sacrifice scores of the physical education teachers participating in the study $\left(\mathrm{F}_{2.102}=5.838 ; \mathrm{p}<0.05\right)$. In the examination made among the 
groups, it was found that physical education teachers residing in the town in sub-dimension were significantly more self-sacrificing than physical education teachers residing in the metropolitan area $(\mathrm{p}<0.05)$.

Table 4. Sub-dimension selfishness one-way ANOVA Test results of physical education teachers participating in the research according to the place of residence

\begin{tabular}{|l|l|l|l|l|l|l|l|}
\hline & & $\mathbf{N}$ & $\overline{\mathbf{X}}$ & $\mathbf{S s}$ & $\boldsymbol{F}$ & $\mathbf{p}$ & Sub-Group \\
\hline \multirow{5}{*}{ Self-Sacrifice } & Town & 51 & 7.9216 & 3.78863 & 7.725 & .001 & Town>Metropolitan \\
\cline { 2 - 8 } & Province & 34 & 10.2059 & 5.03189 & & & \\
\cline { 2 - 8 } & Metropolitan & 20 & 12.5000 & 5.54883 & & & \\
\cline { 2 - 8 } & Total & 105 & 9.5333 & 4.86563 & & & \\
\hline
\end{tabular}

As a result of the comparisons according to the place of residence, a significant difference was found between the selfishness scores of the physical education teachers who participated in the study between the groups $\left(\mathrm{F}_{2.102}=7.725 ; \mathrm{p}<0.05\right)$. In the examination made among the groups, it was found that the physical education teachers residing in the metropolitan city were more selfish than the physical education teachers residing in the town $(p<0.05)$.

Table 5. Altruism one-way ANOVA Test results of physical education teachers participating in the research according to the place of residence

\begin{tabular}{|l|l|l|l|l|l|l|l|}
\hline & & $\mathbf{N}$ & $\overline{\mathbf{X}}$ & $\mathbf{S s}$ & $\boldsymbol{F}$ & $\mathbf{p}$ & Sub-Group \\
\hline \multirow{4}{*}{ Altruism } & Town & 51 & 56.7451 & 10.18203 & 9.932 & .000 & Town>Metropolitan \\
\cline { 2 - 8 } & Province & 34 & 50.7647 & 8.41016 & & & Province>Metropolitan \\
\cline { 2 - 8 } & Metropolitan & 20 & 46.4500 & 8.64794 & & & \\
\cline { 2 - 8 } & Total & 105 & 52.8476 & 10.13351 & & & \\
\hline
\end{tabular}

As a result of the comparisons according to the place of residence, a significant difference was found between the groups of education teachers who participated in the study $\left(\mathrm{F}_{2.102}=\right.$ 9.932; $\mathrm{p}<0.05)$. According to the scores of among the groups, it was determined in altruism sub-dimension that physical education teachers residing in the district were significantly different from the physical education teachers residing in the metropolitan city, and at the same time the physical education teachers residing in the province are significantly different from the physical education teachers residing in the metropolitan area. $(\mathrm{p}<0.05)$.

Investigation of Altruism Levels According To Alma Mater of Physical Education Teachers 
Below, the level of altruism of the physical education teachers participating in the study was examined according to the alma mater variable.

Table 6. Self-sacrifice sub-dimension one-way ANOVA Test results of physical education teachers participating in the study according to alma mater

\begin{tabular}{|c|c|c|c|c|c|c|}
\hline & & $\mathbf{N}$ & $\overline{\mathbf{X}}$ & Ss & $F$ & $\mathbf{p}$ \\
\hline 8 & Institute & 19 & 62.0000 & 7.11805 & 2.819 & .064 \\
\hline ت & Academy & 42 & 60.5952 & 8.39587 & & \\
\hline$\frac{1}{0}$ & College & 44 & 64.2500 & 5.81148 & & \\
\hline & Total & 105 & 62.3810 & 7.30171 & & \\
\hline
\end{tabular}

As a result of the comparisons made according to the alma mater variable, no significant difference was found between the groups regarding the Self-Sacrifice scores of the physical education teachers participating in the research $\left(\mathrm{F}_{2.102}=2.819 ; \mathrm{p}>0.05\right)$.

Table 7. Selfishness sub-dimension one-way ANOVA Test results of physical education teachers participating in the study according to alma mater

\begin{tabular}{|c|c|c|c|c|c|c|c|}
\hline & & $\mathbf{N}$ & $\overline{\mathbf{X}}$ & Ss & $F$ & $\mathbf{p}$ & Sub-Group \\
\hline & Institute & 19 & 12.3684 & 5.43865 & 4.543 & .013 & Institute $>$ College \\
\hline$\stackrel{\mathscr{E}}{\Xi}$ & Academy & 42 & 9.3333 & 4.60999 & & & \\
\hline$\frac{9}{0}$ & College & 44 & 8.5000 & 4.46433 & & & \\
\hline & Total & 105 & 9.5333 & 4.86563 & & & \\
\hline
\end{tabular}

As a result of comparisons made according to the alma mater variable, a significant difference was found between the selfishness scores of the physical education teachers participating in the study between the groups $\left(\mathrm{F}_{2.102}=4.543 ; \mathrm{p}<0.05\right)$. In the examination made among the groups, it was found that the physical education teachers, who graduated from the institute, were significantly more selfish than the physical education teachers who graduated from the college $(\mathrm{p}<0.05)$. 
Table 8. Altruism one-way ANOVA Test results of physical education teachers participating in the study according to alma mater

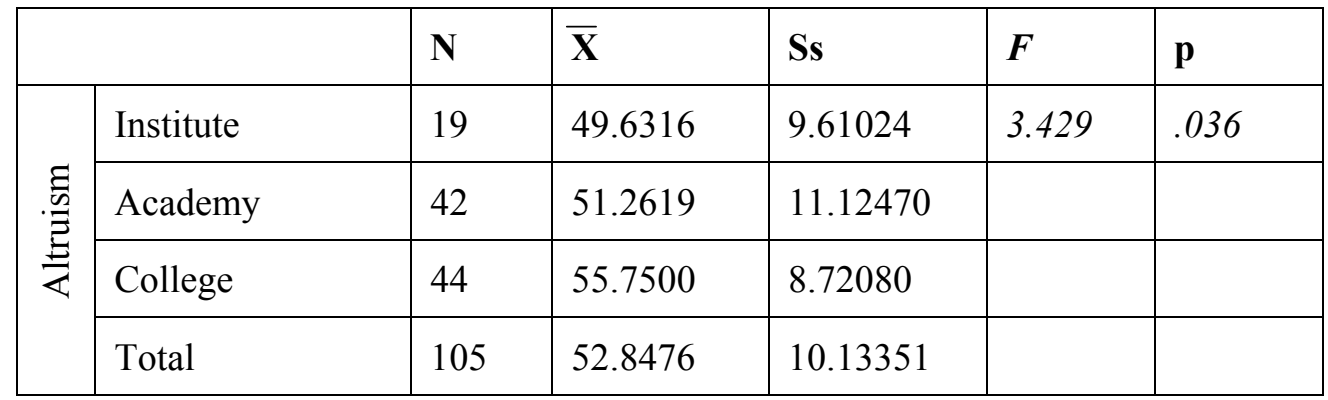

As a result of the comparisons made according to alma mater variable, there was a significant difference at the aspect of altruism scale scores between the groups in terms of physical education teachers participating in the study $\left(\mathrm{F}_{2.102}=3.429 ; \mathrm{p}<0.05\right)$. In the examination made between the groups, no difference was found between the sub-groups in the altruism score $(\mathrm{p}>0.05)$.

\subsection{Investigation of Altruism Levels According to School Variable in which Physical} Education Teachers Work

Below, the levels of altruism of the physical education teachers participating in the study were analysed according to the school variable they work at. However, in this section, the Kruskall Wallis H Test, which is one of the non-parametric tests, was used because the data did not show a normal distribution $(\mathrm{p}<0.05)$ in line with the normality test performed on the data.

Table 9. Kruskall Wallis H Test results according to the school variable in which the physical education teachers participating in the study work

\begin{tabular}{|c|c|c|c|c|c|c|}
\hline & & $\mathbf{N}$ & Average Rank & $d f$ & $\boldsymbol{H}$ & $\mathbf{p}$ \\
\hline \multirow{4}{*}{ 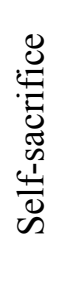 } & Primary School & 31 & 53.08 & 2 & 0.413 & .813 \\
\hline & Secondary School & 39 & 55.12 & & & \\
\hline & High School & 35 & 50.57 & & & \\
\hline & Total & 105 & & & & \\
\hline
\end{tabular}

As a result of the comparisons according to the school variable served, no significant difference was found between the groups regarding the self-sacrifice scores of the physical education teachers participating in the research $(x 2(2, N=105)=0.413 ; p>0.05)$. 


\section{Macrothink}

Table 10. Selfishness sub-dimension Kruskall Wallis H Test results according to the school served variable in which physical education teachers participated in the study

\begin{tabular}{|l|l|l|l|l|l|}
\hline & N & Average Rank & df & H & p \\
\hline Primary School & 31 & 55.23 & 2 & 6.063 & 0.48 \\
\hline Secondary School & 39 & 44.06 & & & \\
\hline High School & 35 & 60.99 & & & \\
\hline Total & 105 & & & & \\
\hline
\end{tabular}

As a result of the comparisons made according to the school variable served, there was a significant difference between the groups in the selfishness scores of the physical education teachers who participated in the study $(x 2(2, \mathrm{~N}=105)=6.063 ; \mathrm{p}<0.05)$. In the sub-group examinations, it was found that physical education teachers working in high school (Average Rank $=60.99)$ had significantly higher selfishness ranges from the physical education teachers working in secondary school (Average Rank $=44.06)(\mathrm{p}<0.05)$. The relevant visual SPSS output was given below as a figure.

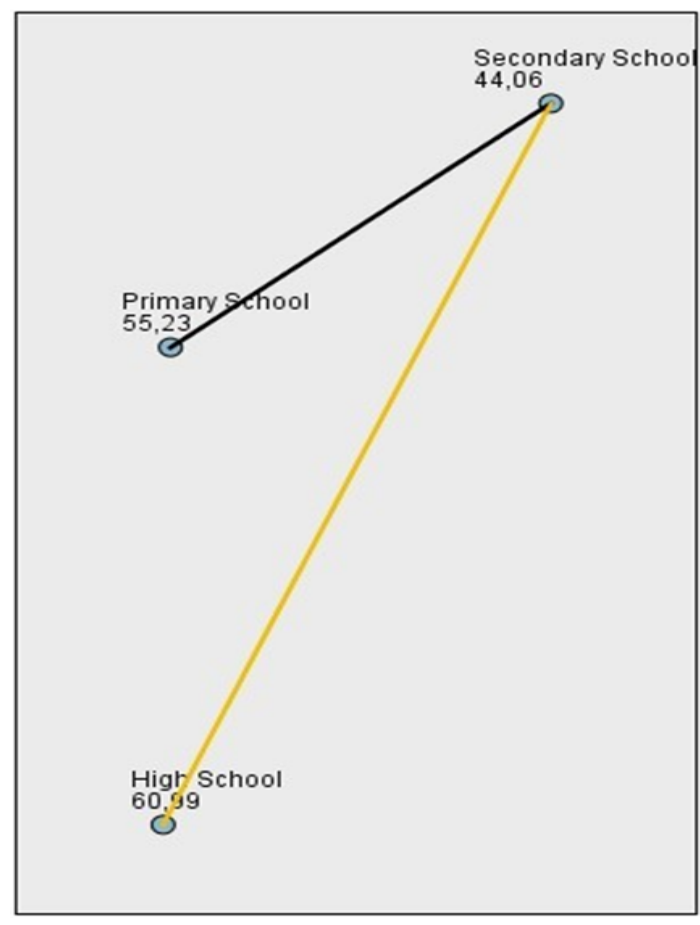

Figure 1. Selfish sub-dimension rank averages of physical education teachers participating in the research

When Figure 1 is examined, it can be seen that the selfishness sub-dimension rank averages of physical education teachers working in secondary school and the line between the 
selfishness sub-dimension rank averages of physical education teachers working in high school are particularly indicated.

Table 11. The results of altruism scale Kruskall Wallis H Test according to the school served variable of the physical education teachers participating in the research

\begin{tabular}{|c|c|c|c|c|c|c|}
\hline & & $\mathbf{N}$ & Average Rank & $d f$ & $\boldsymbol{H}$ & $\mathbf{p}$ \\
\hline \multirow{4}{*}{ 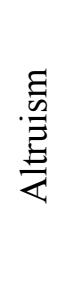 } & Primary School & 31 & 51.31 & \multirow{4}{*}{2} & \multirow{4}{*}{3.971} & \multirow{4}{*}{.137} \\
\hline & Secondary School & 39 & 60.27 & & & \\
\hline & High School & 35 & 46.40 & & & \\
\hline & Total & 105 & & & & \\
\hline
\end{tabular}

As a result of the comparisons made according to the school served variable, there was no significant difference between the groups in Altruism scale scores of the physical education teachers $(\mathrm{x} 2(2, \mathrm{~N}=105)=3.971 ; \mathrm{p}>0.05)$.

\section{Discussion}

When the study was examined, it was found that the gender factor did not have a significant effect on altruism scores (Tables 2, 3, and 4). In the study of Polat and Eynur, although the year of service and age variables were also taken, they were not considered in this study, but there were significant differences between the groups according to the year of service and age variables (Gülaçtı et al., 2017; Polat \& Eynur, 2018). In the study, as the year of professional service increases, the decrease in the level of altruism and the increase in selfishness can be considered as an unexpected result. At the same time, this situation is in contradiction with the findings of the study conducted by Polat (Polat \& Eynur, 2018). However, when the process is examined, this situation can be considered predictable for students who have not graduated from the education faculty. However, it can be considered as a field of study that takes place in the minds after this study, that the acquisition of professional gain may affect the level of altruism. The fact that In the study conducted in Ankara province, no significant difference was observed in altruism scores according to the place of residence, it was noteworthy that the a significant difference $(\mathrm{p}<0.05)$ was detected in the study conducted in Kütahya (Polat \& Eynur, 2018). In addition, the findings obtained from the study show parallels. While examining the findings, it can be predicted that altruism is influenced by many different sociological and environmental parameters. This indicates that it should not be neglected to consider more environmental variables or socio-cultural and socio- economic variables in the formation of altruistic studies. Another similar situation stands out in the studies conducted. In the study, it is considered important because the increase in the level of altruism increases organizational citizenship and the environmental conditions are similar due to the study conducted on a provincial basis (Beğenirbaç \& Meydan, 2012). It is also important that the study was published in an Economic publication. This reveals that social 
variables for different disciplines enable teachers to be affected by many different factors. Similar situation was supported by other studies. It has been stated that the status of altruism, which is one of the gains in citizenship education, is followed up and emerges in studies (Tarman \& Kuran, 2014). It was determined in the study that the self-sacrifice levels of the secondary school teachers in the type of school variable served showed a significantly higher level of self-sacrifice than the physical education teachers working in high school (Table 9). It emphasizes that this situation should also work for educational environments in Kütahya. As a result of the study, it can be said that the teaching formation has similar levels for all our teachers regardless of gender. Teaching profession is a profession that requires self-sacrifice (Can, 2010).

However, according to the findings obtained in the study, when it was examined whether it predicted the altruism sub-dimension of the place of residence according to the hypotheses established by the authors after the linear regression analysis, it was predicted that the sub-dimension of the place of residence was predicted unilaterally significantly ( $\mathrm{fi}=-0.316$; $\mathrm{t}$ $=-3.383 ; \mathrm{p}=0.001 ; \mathrm{p}<0.05)$ and it also valid for altruism scale score $(\mathrm{fi}=-0.402 ; \mathrm{t}=-4.456$; $\mathrm{p}=0.000 ; \mathrm{p}<0.05)$. Despite not being included in the initial hypotheses in the research, this new idea, which emerged in line with the findings obtained, reveals that studies related to altruism should be done by using a method that does not disturb the participants and strategies that support the acquisition of correct and healthy information.

Consequently, altruism is a fact that should be supported and generalized by many studies, as an indispensable and constant feature of attention for the teaching profession. In addition, the opinion that the new measurement tools, which take into account the other altruism positions for each branch, will make a unique contribution to the body of literature is advocated by many writers.

At the end of the study:

a. In line with the difference in altitude levels according to school types, measures to keep teachers' altitude levels high should be taken according to the school type variable.

b. Within the systematic structure of education, studies on altruism from different reference points should be conducted.

c. The different areas of influence of the concept should be further elaborated with different studies in which the other characteristics of the teacher will be examined in the inventory dimension.

\section{Acknowledgements}

Identify grants or other financial support (and the source, if appropriate) for your study; do not precede grant numbers by No. or \#. Next, acknowledge colleagues who assisted in conducting the study or critiquing the manuscript. Do not acknowledge the persons routinely involved in the review and acceptance of manuscripts - peer reviewers or editors, associate editors, and consulting editors of the journal in which the article is to appear. In this paragraph, also explain any special agreements concerning authorship, such as if authors 
contributed equally to the study. End this paragraph with thanks for personal assistance, such as in manuscript preparation.

\section{References}

Acun, I. (2018). Human Rights and Democracy Education. Pegem Academy Publishing.

Arnold, E. (2008). Explaining Altruism: A Simulation-Based Approach and Its Limits. De Gruyter. https://doi.org/10.1515/9783110327571

Bakırcığlu, R. (2016). Encyclopedic Dictionary of Education and Psychology. Memoir Publishing.

Beğenirbaç, M., \& Meydan, C. H. (2012). The Relation of Emotional Labor to Organizational Citizenship Behaviors: A Tool on Teachers. Gazi University Faculty of Economics and Administrative Sciences Journal, 14(3), 159-181. Retrieved from http://search.proquest.com/ openview/5b32ec903be8fe1e2479a0b0fd53ba3f/1?pq-origsite $=$ gscholar\&cbl=2049114

Can, Ş. (2010). The Attitudes of Non-Thesis Graduate Students Towards the Teaching Profession. Muğla University Social Sciences Institute Journal, 24, 13-28. Retrieved from https://dergipark.org.tr/en/pub/musbed/issue/23516/250562

Christ, M. R. (2012). The Limits of Altruism in Democratic Athens. Cambridge University Press. https://doi.org/10.1017/CBO9781139342575

Couture, B. (1998). Toward a Phenomenological Rhetoric: Writing, Profession, and Altruism. Southern Illinois University Press. https://doi.org/10.2307/358970

Dal1, İ. A., \& Özkara, Z. U. (2017). The Mediating Effect of the Authentic Leadership Style on the Relationship between the Administrator's Political Power and Leader Effectiveness, Trust in Him, and Subordinate Altruistic Behaviors: A Study on Nurses. Hacettepe University Institute of Social Sciences.

Down, R. (2011). The Organ Donor Experience: Good Samaritans and the Meaning of Altruism. Rowman \& Littlefield Publishers.

Dugatkin, L. A. (2011). The altruism equation: Seven scientists search for the origins of goodness. The Altruism Equation: Seven Scientists Search for the Origins of Goodness. Princeton University Press. https://doi.org/10.5860/choice.44-3853

Ersanl1, K., \& Çabuker, N. D. (2015). Psychometric Characteristics of the Altitude Scale. Electronic Journal of Social Sciences, 14(52), 43-53. https://doi.org/10.17755/esosder.70589

Fultz, J., \& Schafer, E. D. (2019). Altruism, cooperation, and empathy. Salem Press Encyclopedia of Health. Salem Press. Retrieved from http://search.ebscohost.com/login.aspx? direct $=$ true $\& \mathrm{db}=$ ers $\& A N=93871759 \&$ lang $=$ tr\&site $=$ eds- live.

Grant, C. (2001). Altruism and Christian Ethics. Cambridge University Press. https://doi.org/ 10.1017/CBO9780511488351

Gülaçtı, F., Gür, R., \& Çiftçi, Z. (2017). Investigation of altruism and life satisfaction levels 
of prospective teachers. In Ö. Demirel \& S. Dinçer (Eds.), Education in the global world (pp. 473-484). Pegem Academy. https://doi.org/10.14527/9786053188407.31

Gülsoy, A., \& Topal, M. H. (2018). The Effect of Values, Risk Perception and Nuclear Awareness on the Public Acceptability of Nuclear Plants.

Gürsoy, A., Köksal, K., \& Yapar, H. (2018). The Relationship Between Altruism and Employee Performance: A Study in the Public Sector. Turkey Social Studies Journal, 22(4), 783-96.

Healy, K. J. (2006). Last Best Gifts: Altruism and the Market for Human Blood and Organs. University of Chicago Press. https://doi.org/10.7208/chicago/9780226322384.001.0001

Karasar, N. (2005). Scientific Tooling Method (5th ed.). Nobel.

Koppel, H. (2013). Psychology of Altruism. Nova Science Publishers, Inc.

Kotlikoff, L. J. (2000). Essays on Saving, Bequests, Altruism, and Life-cycle Planning. The MIT Press. https://doi.org/10.7551/mitpress/2829.001.0001

Monroe, K. R. (1996). The Heart of Altruism: Perceptions of a Common Humanity. Princeton University Press.

Oord, T. J. (2008). The Altruism Reader: Selections From Writings on Love, Religion, and Science. Templeton Press.

Öztürk, M., \& Ersanli, E. (2018). Development Of Philanthropy Scale.

Polat, Y., \& Eynur, B. R. (2018). Investigation of the Diǧerkâm (Utility) Levels of Physical Education Teachers Working in Ankara in Terms of Various Variables (p. 414). 16th International Sport Sciences Congress.

Post, S. G. (2003). Research on Altruism \& Love. Templeton Press.

Salter, F. K. (2004). Welfare, Ethnicity and Altruism: New Data and Evolutionary Theory. Routledge.

Scott, N., \& Seglow, J. (2007). Altruism. McGraw-Hill Education.

Seglow, J. (2004). The Ethics of Altruism. Routledge. https://doi.org/10.4324/9780203319918

Smith, B. H. (2014). More Than Altruism: The Politics of Private Foreign Aid. Princeton University Press.

Stark, O. (1995). Altruism and Beyond: An Economic Analysis of Transfers and Exchanges Within Families and Groups. Cambridge University Press. https://doi.org/10.1017/CBO9780 511493607

Swidler, A., \& Watkins, S. C. (2017). A Fraught Embrace: The Romance and Reality of AIDS Altruism in Africa. Princeton University Press. https://doi.org/10.1515/9781400884988

Tarman, B., \& Kuran, B. (2014). The Levels of Learning the Values in Citizenship and 


\section{Macrothink

Democracy Education Course and Teachers' Views on the Relationship between Environment. Gazi Üniversitesi Gazi Eğitim Fakültesi Dergisi, 34(2). https://doi.org/10.17152/gefd.37717

Tekinalp, B. E., \& Icik, Ş. (2013). Current Theories in Psychological Consulting. Pegem Academy Publishing.

Yeşilkaya, M., \& Yıldız, T. (2018). A Research on Social Innovation Tendency on the Axis of Altruistic Behavior. Journal of Entrepreneurship Innovation and Marketing Research, 81-97.

\section{Copyright Disclaimer}

Copyright for this article is retained by the author(s), with first publication rights granted to the journal.

This is an open-access article distributed under the terms and conditions of the Creative Commons Attribution license (http://creativecommons.org/licenses/by/3.0/). 